\begin{tabular}{|c|c|c|c|c|c|c|}
\hline \multirow{4}{*}{ Impact Factor: } & ISRA (India) & $=3.117$ & SIS (USA) & $=0.912$ & ICV (Poland) & $=6.630$ \\
\hline & ISI (Dubai, UAF & $=0.829$ & РИНЦ (Russia) & $=0.156$ & PIF (India) & $=1.940$ \\
\hline & GIF (Australia) & $=0.564$ & ESJI (KZ) & $=8.716$ & IBI (India) & $=4.260$ \\
\hline & JIF & $=1.500$ & SJIF (Morocco) & $=5.667$ & OAJI (USA) & $=0.350$ \\
\hline
\end{tabular}

\section{SOI: $1.1 /$ TAS $\quad$ DOI: $10.15863 /$ TAS \\ International Scientific Journal Theoretical \& Applied Science}

p-ISSN: 2308-4944 (print) e-ISSN: 2409-0085 (online)

Year: 2019 Issue: 07 Volume: 75

Published: $12.07 .2019 \quad \underline{\text { http://T-Science.org }}$
QR - Issue

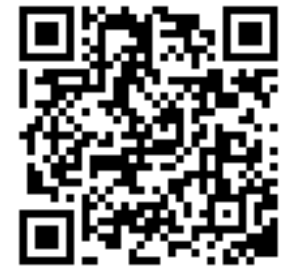

Talantbek Tolibjonovich Madumarov

Andizhan State University

Doctor of Juridical Sciences (DSc), Head of the chair of "National idea, bases of morality and juridical education",

Republic of Uzbekistan

\title{
RELATED REFORMATIONS IN THE DEVELOPMENT OF SMALL BUSINESS AND PRIVATE ENTREPRENEURSHIP IN THE REPUBLIC OF UZBEKISTAN
}

Abstract: In this article has been analyzed related reformations in the development of small business and private entrepreneurship in the Republic of Uzbekistan by the helping literatures and sources.

Key words: reformation, Uzbekistan, development, private entrepreneurship, economy, finance.

Language: English

Citation: Madumarov, T. T. (2019). Related reformations in the development of small business and private entrepreneurship in the republic of Uzbekistan. ISJ Theoretical \& Applied Science, 07 (75), 83-85.

Soi: http://s-o-i.org/1.1/TAS-07-75-16 Doi: crossef https://dx.doi.org/10.15863/TAS.2019.07.75.16

Classifiers: Jurisprudence.

\section{Introduction.}

Nowadays, the development of legal mechanisms for the support of small businesses and the population through the provision of microfinance services and legal regulation of these activities is urgent. This type of financial services is more accessible to the user and consistent with the continual improvement of legal procedures.

Development of small business and private entrepreneurship in Uzbekistan is considered one of the most important and strategic directions of the economy. Therefore, in line with the Decree of the President of the Republic of Uzbekistan dated February 7, 2017 PD-4947, "Strategy of Action in the Five Priorities of Development of the Republic of Uzbekistan in 2017-2021" provides for the balanced and sustained national economy which includes increasing industry, service sector, small business and the share of private entrepreneurship.

Research methods.

According to the President of the Republic of Uzbekistan Sh. M Mirziyoev, a sound and stable banking and financial system is of great importance in the development of the economy. We cannot get rid of the "hidden economy" without increasing the confidence of the population $[1, \mathrm{p} .6]$.

Indeed, the improvement of the microfinance sector, which is the financial support mechanism of the banking and financial system, particularly the small business and private entrepreneurship, provides a large part of the current socio-economic development of the country.

For this purpose, the Decree of the President of the Republic of Uzbekistan on September 12, 2017 "On Additional Measures to Support the Lowsupplied Population", Resolution of the Cabinet of Ministers of the Republic of Uzbekistan No. 857 on October 20, 2017 "the procedure for granting microcredits by commercial banks to provide employment the Low-supplied families", and the micro crediting system is provided with convenience for users of these services improved.

It should be noted that microfinance services are a kind of activity carried out by microcredit organizations, with small amounts of loans and lending to small businesses at low interest rates. Today microcredit organizations have a specific system in Uzbekistan. According to the Central Bank of the Republic of Uzbekistan, currently there are 26 


\begin{tabular}{|c|c|c|c|c|c|c|}
\hline \multirow{4}{*}{ Impact Factor: } & ISRA (India) & $=3.117$ & SIS (USA) & $=0.912$ & ICV (Poland) & $=6.630$ \\
\hline & ISI (Dubai, UAI & $=0.829$ & РИНЦ (Russia & $=0.156$ & PIF (India) & $=1.940$ \\
\hline & GIF (Australia) & $=0.564$ & ESJI (KZ) & $=8.716$ & IBI (India) & $=4.260$ \\
\hline & JIF & $=1.500$ & SJIF (Morocce & $=5.667$ & OAJI (USA) & $=0.350$ \\
\hline
\end{tabular}

microcredit organizations and 42 pawnshops in our country [2].

Of course, this generally represents a more positive picture. However, microcredit organizations and pawnshops show significant differences in the regions. For example, today only one microcredit organization and 3 pawnshops operate [3] in Andizhan region.

At the same time, it is one of the topical issues on forming the legal basis of microcredit organizations, developing special legal acts related to their activities, further development of nonbank microcredit organizations and identifying legal basis for pawnshops activities.

As a proof of our opinion, commercial banks also adopted laws on the provision of microfinance services. This is a great impetus for further development of entrepreneurship in our country.

In this regard, in the context of the title given in the year 2018 "Promoting entrepreneurship, innovative ideas and technologies" by the President of our country, the following points have been expressed in the context of the work that will be of benefit for several people. According to it, as an active entrepreneur, we understand entrepreneurs who are able to produce competitive products and, most importantly, create new jobs and not only provide themselves and their families, but also the whole society. It is our first priority to expand such business classes, to create the best conditions for introducing advanced technology and science-based equipment and equipment and bringing them to our country. And, if necessary, our businessmen should have the opportunity to gain experience in the leading companies and organizations of foreign countries, and provide them with all possible opportunities" $[4, \mathrm{p} .32]$. In this regard significant reforms have been made by the President of our country. As an example, on June 7, 2018, the President of the Republic of Uzbekistan adopt a resolution PR3777 "Every family Entrepreneur". The purpose of the resolution is to improve the material conditions of the population, especially in remote and climatic and far regions of the country, to ensure a significant positive change in the quality and level of life, and permitted to commercial banks to give credits. The procedure for granting loans was issued by the heads of the sector, with a reference of makhallas, with microcredits (LS up to 150-1000 times up to 7\%, with a grace period of up to 6 months and no more than three years).

I would like to say that today the reforms in the country, including small business and private entrepreneurship, are under great importance. In this regard, the head of our state repeatedly says in his speech that "freedom of entrepreneurship and ensuring the protection of private property will continue to be a priority in state policy. I want to emphasize once more that it should be considered as a betrayal for the state policy to block the way of the entrepreneur"[5, p.37].

In the process of organizing joint-stock commercial "Microcreditbank"s, it is necessary to comply with the following requirements: 1) the requirements imposed by the Central Bank on executives; 2) requirements for the management bodies of the bank and its organizational structure; 3 ) requirements for the name of the bank; 4) requirements for the Regulations on domestic credit policy; 5) software requirements for banks; 6) additional requirements for the organization of banks with the participation of foreign capital and requirements for their activities [6].

As noted in the research, in accordance with the laws of the country, you can specify the effect of the following types and combinations of constituent documents of legal entities: the charter; Memorandum and Articles of Association; Memorandum of Association

In terms of constituent documents of microcredit organizations, the author, analyzing the opinions of scientists (Yu.S.Povarov, T.I.Brovchenko) [3] and on the basis of studying the legislation of a number of foreign countries (Russian Federation, Kazakhstan, Belarus, Ukraine) comes to the following conclusion: in civil legislation allowed a combination of constituent documents of a legal entity. And this leads to the emergence of various interpretations in the organization of legal entities and certain unnecessary formalities, and in turn is an artificial obstacle to entrepreneurial activity. That is why it is necessary to unify the constituent documents set forth in Article 43 of the Civil Code (charter, memorandum of association, provision), to prevent their combinations. To this end, it is necessary to combine the first and second parts of the 43-th article of the Civil Code, to develop and adopt a new edition, while it is necessary to unify the types of constituent documents. That is why the norm must be stated in the following formulation:

Legal entities, with the exception of business partnerships, operate on the basis of a charter approving them by the founders (participants). Business partnerships operate on the basis of a memorandum of association drawn up by the founders (participants) and to which the rules of this code on the statute of a legal entity apply.

When organizing a microcredit organization in the form of joint-stock companies, a combination of constituent documents is allowed. In this case, first the founder or the founders decide on the establishment. If the joint-stock company is organized by two or more persons, then the foundation agreement will be drawn up between the founders. After that, if a jointstock company is organized by two or more persons, the charter is approved at a constituent assembly, in the case of a joint-stock company being established by one founder, the charter is approved by that person. 


\begin{tabular}{|c|c|c|c|c|c|c|}
\hline \multirow{4}{*}{ Impact Factor: } & ISRA (India) & $=3.117$ & SIS (USA) & $=0.912$ & ICV (Poland) & $=6.630$ \\
\hline & ISI (Dubai, UAE & $=0.829$ & РИНЦ (Russia & $=0.156$ & PIF (India) & $=1.940$ \\
\hline & GIF (Australia) & $=0.564$ & ESJI (KZ) & $=8.716$ & IBI (India) & $=4.260$ \\
\hline & JIF & $=1.500$ & SJIF (Morocco & $=5.667$ & OAJI (USA) & $=0.350$ \\
\hline
\end{tabular}

However, it should be noted that the Law on JointStock Companies does not establish provisions on the approval of its charter in the case of establishment by one founder. And this in turn can lead to the emergence of various interpretations in practice. Because the procedure for the approval of the charter of a joint-stock company with one founder is abstract and there is a gap in the legislation in terms of the approval of the charter by the founder or later by the participants. To eliminate this gap, it is advisable to supplement the second part of Section 1 of the article of the Law "On Joint-Stock Companies and Protection of Shareholders' Rights" with the following provision [2, p.43]:

If the company is established by one founder, the decision on the approval of the company's charter is taken by this founder unilaterally. The first and second part of the 11th article of the Law of the Republic of Uzbekistan "On Limited and Additional Liability Companies" should be stated as follows:

The company's charter is the constituent document of the company. If a company is established by one person, the charter approved by that person is considered to be the constituent document of the company. If the number of participants in the company is increased by two or more people, the charter shall be approved by the constituent agreement drawn up between them.

\section{In conclusion.}

The research work also justifies the fact that it is necessary to exclude the rules relating to the memorandum of association provided for in Article 12 and a number of important provisions set forth in this article to be included in Article 13 of this law, defining the rules relating to the company's charter.

In accordance with the Laws of the Republic of Uzbekistan "On the Central Bank of the Republic of Uzbekistan", "On Microcredit Organizations", "On Licensing Certain Types of Activities" dated May 25, 2000, as well as the Resolution of the President of the Republic of Uzbekistan dated May 12, 2001 "On the list of licensed activities "And 1 appendices to this resolution, the activities of microcredit organizations are classified as licensed activities, which is enshrined in the Regulation" On the procedure for licensing activities of microcredit organizations ", its approved Resolution of the Board of the Central Bank of the Republic of Uzbekistan dated January 23, 2010 № 3/5 (registration number 2093, April 13, 2010).

In accordance with Article 17 of the Law "On Microcredit Organizations", the reorganization and liquidation of a microcredit organization is carried out in accordance with the legislation. From this point of view, the reorganization and liquidation of the microcredit organization is carried out.

\section{References:}

1. (2017, December 20). Proclamation of The President of The Republic of Uzbekistan Sh. Mirziyoev To The Oliy Majlis. Khalk Suzi.

2. (n.d.). Retrieved 2019, from http://www.cbu.uz/

3. (n.d.). Information from the central bank of the Andizhan region headquarters.
4. Mirziyoev, S. M. (2018). The consent of our people is the highest value given to our work. "Uzbekistan".

5. (2017, December 27). Khalk Suzi.

6. (2017, December 20). Khalk Suzi. 